\title{
EVALUATION OF TAX CRIMINAL LAW (REGULATION-PRACTICE-TRIAL)
}

\author{
Yusuf KARAKOÇ ${ }^{1}$
}

\begin{abstract}
Illegalities about the tax-related duties are regulated in the Tax Procedure Law as Tax Misdemeanors and Tax Crimes according to their qualities and the weight of injustice of the action in tort. Although these provisions, which underlie the Tax Criminal Law, have not systematical significant deficiencies, it is encountered the problems concerning today's conditions and about the compliance with the Turkish Penal Code and the Misdemeanor Law. In this context, there are deficiencies of Tax Criminal Law relating to regulation, practice and trial. In this study, a general evaluation of Tax Criminal Law is carried out; problems are identified, and solutions are offered. This study is expected to contribute to the progressing preparatory work for an extensive alteration to the Tax Procedure Code.
\end{abstract}

Keywords: Tax Criminal Law, Tax Misdemeanors, Tax Crimes, Tax Procedure Law, Turkish Penal Code, Misdemeanor Law

JEL Code: K14, K34, K42.

\section{Introduction}

The tax law relationship is a public law-based relationship between State and persons. This relationship must be run in accordance with the rules that serve to regulate this relationship. But it is known that in some cases taxpayer and tax responsible may violate the law intentionally or unintentionally. Unlawful acts are a subject of different types of tax offenses and / or misdemeanors depending on their qualifications and different punishments are imposed on these offenses and / or misdemeanors. The section of the tax law that is related to the acts against to tax code and their punishments and/or sanction is called as Tax Criminal Law.

It is encountered with difficult situations with respect to today's conditions and compliance with the regulations of the Turkish Penal Code and the Misdemeanor Law, although there are no systematically significant shortcomings in the regulations that form the basis of Tax Criminal Law and take place in Tax Procedure Code. In this regard, there are deficiencies of Tax Criminal Law on regulation, practice and trial. In this study, a general evaluation of Tax Criminal Law is carried out; problems are identified, and solutions are offered. This study is expected to contribute to the progressing preparatory work for an extensive alteration to the Tax Code ${ }^{2}$.

\footnotetext{
1 Prof. Dr. Dokuz Eylül University Law Faculty, Department of Fiscal Law.

2 Since the paper is not an article and there is a limitation about total page and word, to submit detailed explanation and references have not been possible, it has been contented with selected bibliography.
} 


\section{The Subject and the Scope of the Tax Criminal Law}

Tax Criminal Law examines punishment or sanctions relative to crimes and misdemeanours arising from acts contrary to tax laws. Tax crimes and misdemeanours are, as a rule, accepted as (fiscal) crimes and misdemeanours committed against the State Treasury. The purpose of the tax crimes and misdemeanours and sanctions imposed them is to ensure the timely and proper implementation of tax laws. The timely and proper payment of the taxes prevents both the reduction of the Treasury's income and serves the collection of public revenues which constitute the financial source of public services in turn public interests.

The subjects of the tax criminal law are the illegal acts against to Tax Law that named crimes and misdemeanours; also, their punishment and sanction. In this respect, it is important to note that use only Tax Procedure Code at resolution of disputes or conflicts arising from the implementation of the Tax Criminal related rules will be inadequate. Because Tax Procedure Code is not the only Code that regulate sanctions and punishment of the acts contrary to Tax law. The unlawfulness on the collect stage of public revenues is regulated by Public Receivables Collection Procedure Code. This Code includes some crimes and their punishments. Also, Customs Code and Anti-smuggling Code include parallel regulations with Tax Procedure Code about crimes and misdemeanours. For this reason, this other Codes should be taken into consideration when make arrangements in the field of Turkish Tax Criminal Law. Otherwise, different degree, contradictory, contrary sanctions will appear about the unlawfulness on the same law field.

\section{Assessment of the Tax Criminal Law}

- In the case that Tax Criminal Law, broadly defined as Financial Criminal Law, it will not be limited with the Tax Procedure Law; the crimes and misdemeanors which are regulated in Public Receivables Collection Procedure Code, Customs Code and Anti-smuggling Code should be included. Currently, Tax Criminal Law refers to Tax Criminal Law in the narrow sense based on only the Tax Procedure Code. In this field, regulations, practice and trials are made based on this qualification only. But legal system should be considered as a whole. The Financial Criminal Law that serves the same legal interest should be considered and keep in mind together. It is necessary to harmonize these regulations, considering the need to create a whole. Otherwise, it is not possible to reach justice and to provide legal security with incompatible and nonproportional regulations-practice-trials.

- Penalties do not direct correspond to the sustained loss and / or the cost; it should have a deterrent effect. However, it should not have a lethal-destructive-ruinous effect. Therefore, the penalties must be certainly and clearly defined in the Law, by taking into account the inflation and current interest rate and the principles of legality -legal security-certainty.

- Taxpayers who cause a tax loss are subject to a penalty corresponding to half of, onefold or three-fold of the tax loss. The sanctions defined as "fold" are considered as nonproportional, over-punitive and impossible to obey.

- It is necessary to make it known that some part of the acts of special irregularity is a subject of the tax loss misdemeanors as for the other part of them is an attempt of smuggling crime. As a consequence of this, if tax loss penalty and/ or custodial sentence about tax smuggling are applied after the closure of the accounting period, the special 
tax irregularity penalty should not be applied. Special tax irregularity penalty should be applied as result of the illegal acts that in accounting period.

- In order to prevent to penalty concentration, the single punishment should be given for the misdemeanors that are committed by the same act.

- It is necessary to apply administrative fine for tax smuggling acts if they also cause tax loss. But in this case, basic tax loss penalty should be applied and waited for to give additional punishment until a decision of the court approve that crime is actually committed and it is committed by taxpayer. Unless this proposal is implemented, conflicting court decisions in positive law will be continuing to exist.

- The application of penitence and rectification should continue to prevent of apply tax loss penalty; but the connection to the non-prosecution of smuggling crime (connivance) should be corrected. In case of taxpayer's application of penitence and rectification, criminal investigation and prosecution should be continued; however, the benefit from penitence and rectification regulations and the fulfilment of their conditions should be accepted as a reason for discounting.

- The structure of the conciliation commissions, the nature of their decisions- effects and consequences should be clarified. The relations between conciliation- judicial remedy; conciliation- remission of fines should be clarified. If taxpayers apply for penitence and rectification, they should also be benefit from the remission of fines. Infringement to the conclusions of conciliation should result in the cancel of the conciliation.

- The rate difference should be eliminated in remission of tax fines. The same discount rate should be determined and applied for all tax penalties. Otherwise, the nonproportional, bizarre results will appear inevitably.

- The existence of recidivism causes many problems. There is no way to eliminate these drawbacks completely. Therefore, the repeal of the regulation that regulates the increasing of the sentence in case of repetition is the most appropriate solution. But the situation of the taxpayers who commit a tax misdemeanor over and over again should be considered when they apply to favored regulations like conciliation and deferment.

- It would be useful to clarify the issue of successive offense and the laps of times. The topics of separately punishment of the crimes that are committed at the same accounting/ taxation period, the increasing punishment because of their characterization as successive offense, the acceptance of the successive crime until the determination of the crime should be discussed. And fair- reasonable regulation should be made as a result. And also there is a necessity of clear regulations about specifies the date of the crime on tax smuggling crimes that does not cause the tax loss to determine to start of the laps of time.

- The definition and scope of the breach of tax secrecy and conducting personal affairs of taxpayers should be made clearer and more proper also their punishment should be regulated in Turkish Tax Procedural Code instead of the reference to the Turkish Criminal Code. Besides, the crimes and misdemeanors that are regulated in different part of the Tax Procedure Law or other laws, should be collected in the section of tax crimes, misdemeanors and offences in Turkish Tax Procedure Code. 


\section{Conclusion}

- The penalties which are expressed in terms of "fold", should be given up. It is considered proper to regulate to basic penalty corresponding to half of the tax loss, also reduced penalty corresponding to quarter, aggravated penalty corresponding to one-fold of the tax loss, considering current inflation and current interest rate.

- It is known that applying both custodial sentence and three-fold tax loss penalty in case that tax smuggling act also cause tax loss is discussed with regards to both domestic law and case-law of the European Court of Human Rights. First, contradiction between the relevant provisions of the Tax Procedural Code (VUK.m.344, 359) and the third paragraph of Article 15 of the Law on Misdemeanors is considered as a reason of discussion. This contradiction can be partially resolved within the context of the special law-general law, the lex posterior - legi priori. However, complete termination of the discussions is not possible. The fact that the same verb causes for trial twice is contradictory with the effect of definitive judgment and the rule of non bis in idem. Double jeopardy is not possible; and no decision / penalty can be given twice based on the same reason. But currently the sanctions are not the same nature so it may be considered as legitimate.

- The administrative fines are not the sanctions in the same nature with the liberty binding punishments (custodial sentence). As a result, an administrative fine is imposed for tax loss; and the offender shall be punished with a liberty binding punishment because of the criminal nature of the act. There is no legal obstacle to do this. But three-fold tax loss penalty must be terminated, instead of it, an amount of judicial fine should be preferred in addition to custodial sentence. In positive law, causing of the tax smuggling is considered as aggravating circumstance of the tax loss misdemeanors. But instead of this, tax loss should be regulated as an aggravating circumstance of the tax smuggling crime. The payment of the administrative fine also should be considered as extenuating circumstance.

- The conversion of the courts that make judicial proceedings on tax crimes to the court with special authority will be useful. In this context, in the case of the establishment of a financial police-prosecution-court chain, tax crimes and criminals will be followed healthier. Also, the court of appeal must be the same department of the Judicial Council about the illegality to Tax Procedure Code and Anti-Smuggling Code to provide coherent case-law.

- It should not be forgotten that, law system is a whole, and stability is essential to constitute of law.

- Shortly and precisely; a foreseeable, obeyable, applicable tax penalty system should be established.

\section{References}

\section{Books}

Bayar, ì. (2013). Vergi Kaçakçılığı, Ankara, Mali Akademi Yayınları.

Baykara, B. (2009). Teori ve Pratik Yönleriyle Vergi ve Vergi Ceza Hukuku, İstanbul, Maliye Hesap Uzmanları Derneği.

Candan, T. (2019). Vergisel Kabahatler ve Suçlar, 4. Baskı, Ankara, Yetkin Yayınları. 
Donay, S. (2008). Ceza Mahkemesinde Yargılanan Vergi Suçları, , İstanbul, Beta Yayınları, (Vergi Suçları).

Erdem, T.(2010). Vergisel Kabahatler, İstanbul,Beta Yayınları, (Vergisel Kabahatler).

Erman, S. (1988). Vergi Suçları, İstanbul, (Vergi Suçları).

Karakoç, Y. (1977).Türk Vergi Ceza Hukukunda Pişmanlık ve Islah, 2. Bası, İzmir, DEÜHF. Döner Sermaye İşletmesi Yayınları No: 76, (Pişmanlık).

Karakoç, Y. (2017). Vergi Yargılaması Hukuku (Vergi Anlaşmazlıklarının/Uyuşmazlıklarının Çözüm Yolları), 4. Baskı, , Ankara,Yetkin Yayınları, (Vergi Yargılaması).

Karakoç, Y. (2016). Vergi Ceza Hukuku, Ankara,Yetkin Yayınları, (Vergi Ceza).

Kaşıkçı, M. (2007). Türk Hukukunda Vergi Kaçakçılığı Suçları, İstanbul,Ethemler Yayıncılık, (Vergi Kaçakçılığı).

Mutluer, M. K. (1979).Vergi Ceza Hukuku, , Eskişehir,Eskişehir iтiA. Yayınları No: 214, (Vergi Ceza).

Özcan, O. (2015). Vergi Suçları, Ankara, Seçkin Yayınları.

Şenyüz, D. (2015). Vergi Ceza Hukuku, 8. Baskı, Bursa, Ekin Yayınevi, (Vergi Ceza).

Taşdelen, A. (2010). Vergi Usul Kanunu Yönünden Vergi Kabahatleri, Ankara, Turhan Kitabevi.

Uğur, H. - Elibol, M. (2015).Açıklamalı-Içtihatı Vergi Suçları, Ankara, Adalet Yayınevi.

\section{Journals/Periodicals}

Akkaya, M. (2000). "Vergi Muhakemesi ve Ceza Muhakemesi Kararlarının Etkileşimi Üzerine Bir İnceleme", AÜHFD., C. 49, S. 1-4, ss. 85-96, (Kararların Etkileşimi).

Akkaya, M. (2008). "İdari ve Adli Vergi Ceza Sistemine Eleştirel Bir Bakış”, Vergi Sorunları Dergisi, Şubat, S. 233, Özel Sayı: Vergi Ceza Sistemi, ss. 29-35, (Ceza Sistemi).

Aydın, A. R. (2008). "Vergi Suç ve Ceza Sisteminin Anayasal Çerçevesi", Vergi Sorunları Dergisi, Şubat, S. 233, Özel Sayı: Vergi Ceza Sistemi, ss. 13-28.

Bağdanlı, İ. H. (2008). "Vergi Usul Kanununa Göre Vergi Ceza Sisteminin Uygulama Esasları", Vergi Sorunları Dergisi, Şubat, S. 233, Özel Sayı: Vergi Ceza Sistemi, ss. 36-51.

Başaran, F. (2006). “idari Nitelikli Vergi Suç ve Cezaları”, Vergi Dünyası, S. 299, Temmuz, ss. 116147, (İari Nitelikli).

Başaran Yavaşlar, F. (2008). “Vergi Ceza Hukuku'ndaki Değişim Süreci ve Bu Sürecin Vergi Ceza Sistemine Etkileri”, Vergi Sorunları Dergisi, Şubat, S. 233, Özel Sayı: Vergi Ceza Sistemi, ss. 72-94, (Vergi Ceza Sistemi).

Başaran Yavaşlar, F. (2008). "Vergi Suç ve Kabahatleri Hukuku’nda Son Durum”, iBD., C. 82, S. 2008/6, ss. 2839-2859, (Son Durum).

Demirbaş, B.(2009) "Vergi Ceza Hukuku’nun Anayasal Temelleri”; Prof. Dr. Muallâ ÖNCEL'e Armağan, C. II, Ankara Üniversitesi Yayınları No: 243, Ankara, ss. 953-985. 
Doğrusöz, A. B. (2005). "Türk Ceza Hukukundaki Gelişmelerin Vergi Ceza Hukukuna Etkisi”, Legal Malî Hukuk Dergisi, Ocak, S. 1, ss. 21-29, (Vergi Ceza).

Doğrusöz, A. B. (2008). "Vergi Ceza Sistemine Yönelik Eleştiriler", Vergi Sorunları Dergisi, Şubat, S. 233, Özel Sayı: Vergi Ceza Sistemi, ss. 95-101, (Eleştiriler).

Karakoç, Y. (1996). “Ceza Mahkemesinde Yargılanacak Vergi Suçları Hakkında Kamu Davası Açılmasının Mütalâa Şartına Bağlı Olması", (Yusuf Karakoç, Yargı Kararları Işığında Vergi Sorunlarının Çözümü, İzmir 1996, s. 53-62), (Mütalâa Şart).

Karakoç, Y. "Vergi Ziyaı Suçu ve Cezası”, Manisa Barosu Dergisi, Yıl: 18, S. 71, ss. 40-55, (Vergi Ziyaı).

Karakoç, Y. (2012). "Türk Vergi Ceza Hukuku Üzerine Bir Değerlendirme”, Dokuz Eylül Üniversitesi Hukuk Fakültesi Dergisi, C. 12, Özel Sayı, 2010, Prof. Dr. Burhan CEYHAN Anısına Armağan, C. I, İzmir, ss. 3-26, (Değerlendirme).

Karakoç, Y. (2014). "Anayasal Vergilendirme IIlkeleri Üzerine Bir Değerlendirme”, Dokuz Eylül Üniversitesi Hukuk Fakültesi Dergisi, C. 15, Özel Sayı, 2013, Prof. Dr. M. Polat SOYER'e Armağan, C. II, İzmir, ss. 1259-1308, (Vergilendirme Illkeleri).

Karakoç, Y. (2015). “Vergi Cezası Anlaşmazlıklarının Çözüm Yollarından Cezalarda İndirim Müessesesi", Dokuz Eylül Üniversitesi Hukuk Fakültesi Dergisi, C. 16, Özel Sayı, 2014, Prof. Dr. Hakan PEKCANITEZ'e Armağan, C. IV, İzmir, ss. 3637-3739, (Cezalarda İndirim).

Oktar, S. A. (1988). "Vergi Suçunun Niteliği Üzerine Bazı Düşünceler", iüifM., 49. Cilt, 760. Yıl Özel Sayısı, İstanbul 1998, ss. 165-174, (Vergi Suçunun Niteliği).

Oktar, S. A. (2000). "Kaçakçılık Suçları Üzerine Düşünceler”, Vergi Sorunları Dergisi, Eylül 2000, S. 144, ss. 75-93, (Kaçakçılık Suçları).

Öğütçü, B. (2008). "Vergi İnceleme Raporu ve Sahte veya Muhteviyat İtibariyle Yanıltıcı Belge”, iBD. Vergi Hukuku Özel Sayısı, Mart, ss. 125-146.

Önok, R. M. - Pınar, B. (2006). “Kesin Hüküm Müessesesi Bağlamında Ceza Mahkemesi Kararları İle Vergi Mahkemesi Kararlarının Birbirini Etkileşimi ve Bağlayıcılığı Üzerine Bir İnceleme”, Mali Pusula, Temmuz, S. 19, ss. 67-89.

Şengöz, Y. (2008). “Vergi Ceza Hukukunda Kaçakçılık Suçunun Suç Tarihi, Dava Zamanaşımı Süresi ve Başlangıcı", Vergi Sorunları Dergisi, Şubat, S. 233, Özel Sayı: Vergi Ceza Sistemi, ss. $121-137$.

Şenyüz, D.(2013). "Susma Hakkı Karşısında Vergi Usul Kanunundaki Defter ve Belgeleri Gizleme (Kaçakçılık) Suçu", DEÜHFD., C. 15, S. 1, ss. 29-40, (Susma Hakkı).

Uludağ, B. - Güçlü, E. B. (2008). "Vergi Suçlarında Birleşme”, Vergi Sorunları Dergisi, Şubat, S. 233, Özel Sayı: Vergi Ceza Sistemi, ss. 167-175.

Yalt, B. (2008). "ilkesel Düzeyde Vergi Ceza Sistemi Tasarımı: Oranthlılık IIlkesi Uygulaması”, Vergi Sorunları Dergisi, Şubat, S. 233, Özel Sayı: Vergi Ceza Sistemi, ss. 102-109. 